\title{
Polyporales and similar poroid genera (Basidiomycota) from Parque Estadual da Serra do Mar, São Paulo State, Brazil ${ }^{1}$
}

\author{
Ricardo Matheus Pires ${ }^{2,3}$, Viviana Motato-Vásquez ${ }^{2}$, Mauro Carpes Westphalen ${ }^{2}$ and \\ Adriana de Mello Gugliotta ${ }^{2}$
}

Received: 9.11.2016; accepted: 3.02.2017

\begin{abstract}
Polyporales and similar poroid genera (Basidiomycota) from Parque Estadual da Serra do Mar, São Paulo State, Brazil). This survey presents the first species list of the poroid fungi (Polyporales and related genera) from Parque Estadual da Serra do Mar, Núcleo Santa Virgínia, the largest area of the Atlantic forest in Brazil. A total of 68 species, 38 genera and ten families were found in the studied area. Antrodiella luteocontexta, Ceriporiopsis flavilutea, Diplomitoporus navisporus, Flaviporus venustus, Grammothele fuligo, Oxyporus latemarginatus, Perenniporia cremeopora, Postia subcaesia and Postia tephroleuca are recorded for the first time to São Paulo State and Dichomitus campestris and Postia undosa represent the first records in Brazil. Full description of the new records in Brazil, comments about the new records in São Paulo State, as well as pictures and an identification key are provided.

Keywords: Brazilian Atlantic forest, Fungal diversity, Neotropics, Taxonomy
\end{abstract}

RESUMO - (Polyporales e gêneros poroides semelhantes (Basidiomycota) do Parque Estadual da Serra do Mar, Estado de São Paulo, Brasil). Esta pesquisa apresenta a primeira lista de espécies dos fungos poroides (Polyporales e gêneros relacionados) do Parque Estadual da Serra do Mar, Núcleo Santa Virgínia, a maior área de Mata Atlântica no Brasil. Um total de 68 espécies, 38 gêneros e dez famílias foram encontradas na área estudada. Antrodiella luteocontexta, Ceriporiopsis flavilutea, Diplomitoporus navisporus, Flaviporus venustus, Grammothele fuligo, Oxyporus latemarginatus, Perenniporia cremeopora, Postia subcaesia e Postia tephroleuca são registradas pela primeira vez para o Estado de São Paulo e Dichomitus campestris e Postia undosa representam o primeiro registro no Brasil. A descrição completa dos novos registros no Brasil, comentários sobre os novos registros no estado de São Paulo, fotos e uma chave de identificação são fornecidos.

Palavras-chave: Mata Atlântica brasileira, diversidade fúngica, neotrópico, taxonomia

\section{Introduction}

Polypores belong to class Agaricomycetes Doweld in the Basidiomycota; they grow mostly lignicolous and are characterized by the presence of a hymenophore formed by parallel tubes that lead into a surface composed by pores, which are inseparable from the context, a feature that makes them different from Boletales E.J. Gilbert (Ryvarden 1991). These fungi are extremely important for nutrient cycling and play a fundamental role in wood decay due to their system of lignocellulolytic enzymes (Ryvarden 1991, Begon et al. 2006).

Polyporales Gäum. is considered one of the most problematic groups of fungi from a taxonomic and systematic viewpoint. Based on molecular phylogenetic results, the order has been divided into four lineages, the 'antrodia clade', the 'polyporoid clade', the 'phlebioid clade', and a 'residual polyporoid clade', which often unite genera previously considered unrelated (Hibbett \& Donoghue 1995, Larsson et al. 2004, Binder et al. 2005; 2013, Garcia-Sandoval et al. 2011, Miettinen et al. 2011). The position of the 'residual polyporoid clade' remains uncertain and some taxa (e.g. Gelatoporia Niemelä, Grifola Gray and Tyromyces P. Karst) apparently do not belong to any of these main lineages. Families such as Hydnodontaceae Jülich and Schizoporaceae Jülich and many polyporoid genera as Trichaptum Murrill (Incertae sedis) are included in the order Hymenochaetales. However, poroid taxa are morphologically and ecologically related and have

1. Parte da Dissertação de Mestrado do primeiro Autor

2. Instituto de Botânica, Núcleo de Pesquisa em Micologia, Av. Miguel Stefano 3.687, 04301-012 São Paulo, SP, Brasil

3. Corresponding author: sals.bio@gmail.com 
been historically studied together; for this reason, also poroid genera not belonging to Polyporales were included in this study.

Many studies on polypores have been carried out in Brazil, and many of them in areas of the Atlantic forest (Bononi et al. 1981, Jesus 1993, Gugliotta \& Bononi 1999, Xavier-Santos et al. 2004, Louza \& Gugliotta 2007, Leal \& Gugliotta 2008, Abrahão et al. 2009, Baltazar \& Gibertoni 2009, Gugliotta et al. 2010, 2011, 2015, Westphalen \& Silveira 2008, 2013, Westphalen \&. 2010, Motato-Vásquez \& Gugliotta 2014, Motato-Vásquez et al. 2015, Pires \& Gugliotta 2016). The Atlantic forest, which originally occupied $1,315,460 \mathrm{~km}^{2}$ of Brazilian territory, presently only covers about $8 \%$ of its original area (Fundação SOS Mata Atlântica and INPE 2009, 2011), being placed in the top five list of the biologically richest and most threatened regions (biodiversity hotspots) on the planet (Mittermeier et al. 2004). In Brazil, the Atlantic forest includes the second largest area of tropical forest ecosystem, including different types of vegetation as ombrophilous, mountain, inland and Araucaria forest (Secretaria de Estado de Meio Ambiente 1996). São Paulo State contains a significant portion of this important phytogeographic domain, with $26,703.24 \mathrm{~km}^{2}$, which occurs mainly along the coast and on the slopes of Serra do Mar, corresponding to $15.78 \%$ of the state's territory (Fundação SOS Mata Atlântica and INPE 2011).

Parque Estadual da Serra do Mar represents the largest continuous area of preserved Atlantic forest in Brazil (Secretaria de Estado de Meio Ambiente 2008); however, so far little is known about the community of poroid fungi. This study was aimed to survey species included in Polyporales and similar genera of poroid fungi present in the park. A list of recorded species, descriptions of the new records in Brazil, comments on the new records in São Paulo State, and an identification key are provided.

\section{Materials and methods}

Parque Estadual da Serra do Mar (PESM), managed by Instituto Florestal, is a protected area that hosts the largest area of Atlantic forest in Brazil. With $3,153.9 \mathrm{~km}^{2}$, it encompasses 11 coastal municipalities and 15 municipalities located on the Atlantic Plateau in São Paulo state (Secretaria de Estado de Meio Ambiente 2000). Due to the extent of the park and the heterogeneity of its socio-cultural, historical and environmental features, it is managed in eight units.
Among these, the Núcleo Santa Virgínia $\left(45^{\circ} 03^{\prime}\right.$ to $45^{\circ} 11^{\prime} \mathrm{W}$ and $23^{\circ} 24^{\prime}$ to $23^{\circ} 17^{\prime} \mathrm{S}$ ) is located in the municipality of São Luiz do Paraitinga and Natividade da Serra. The unit covers a total area of $170 \mathrm{~km}^{2}$, with altitudinal range of $860 \mathrm{~m}$ to $1650 \mathrm{~m}$, and maximum temperature of $35^{\circ} \mathrm{C}$, medium $21^{\circ} \mathrm{C}$, and minimum $-3^{\circ} \mathrm{C}$ (Secretaria de Estado de Meio Ambiente 2008).

A permit for sampling in the park was issued by the Instituto Florestal (Carta COTEC no ${ }^{\circ} .155 / 2013$ D201/2011 PGH). Collections in the study area were carried out bimonthly from April 2013 to February 2015 and all studied materials were collected by Ricardo M. Pires. The basidiomata were photographed, georeferenced, collected with a knife, and individually packed in paper bags. Data such as date of collection, collector number, substrate, color and other macroscopic features were noted (Fidalgo \& Bononi 1984). Macroscopic analysis included description of features such as: habit and habitat of the basidiomata; shape, surface, margin and size of the pileus, color, shape and number of pores per millimeter; shape, color, consistency, surface, apex, base and size of the stipe (when present). The color was described according to Küppers (2002).

For microscopic analysis, freehand cuts were performed in cross sections of the tubes to observe the hymenium and trama structures. The sections were treated with $\mathrm{KOH} \mathrm{5 \%}$ solution and stained with 1\% Phloxine. Melzer's reagent was used for evidence of amyloid and dextrinoid reactions. The sections were observed under a Leica DM1000 optical microscope. The structures were analyzed and described based on color, cell walls, reactions and size of the basidiospores; shape, color, wall, sterigmate number and size of basidia; shape, color and size of sterile elements; and color and type of hyphae. Twenty to 30 measurements were taken from each structure present. Measurements of the length and width of basidiospores, basidia (without sterigmata), and cystidia were also taken. For basidiospores, the measurement of $Q$ represents the variation of the ratio between the length and the width of approximately 100 basidiospores of each species, and Qm that represents the average value of Q (Coelho 2005). The specimens were deposited at the Herbarium Maria Eneyda P. K. Fidalgo (SP) of the Instituto de Botânica. The literature consulted for identification were mainly Lowe (1966), Ryvarden \& Johansen (1980), Ryvarden (1991) and Ryvarden \& Gilbertson (1993, 1994), as well as all the specialized literature from which the distribution data of the species was extracted (see below the entries for new records). 


\section{Results and Discussion}

A total of 68 species, 38 genera and ten families were found in the study area. Dichomitus campestris (Quél.) Domanski \& Orlicz and Postia undosa (Peck) Jülich are recorded for the first time for Brazil. Furthermore, Antrodiella luteocontexta Ryvarden \& de Meijer, Ceriporiopsis flavilutea (Murrill) Ryvarden, Diplomitoporus navisporus Gibertoni \& Ryvarden, Flaviporus venustus A. David \& Rajchenb., Grammothele fuligo (Berk. \& Broome) Ryvarden, Oxyporus latemarginatus (Durieu \& Mont.) Donk, Postia subcaesia (A. David) Jülich and Postia tephroleuca (Fr.) Jülich are recorded for São Paulo state for the first time.

Antrodiella luteocontexta Ryvarden \& de Meijer

Figures 1-3

\section{Polyporales, Phanerochaetaceae}

Description: Ryvarden \& de Meijer (2002).

Remarks: the species is characterized by the pileate and annual basidioma with imbricate, broadly sessile and gregarious pilei, yellow context (Küppers color chart: $\mathrm{N}_{00} \mathrm{~A}_{60} \mathrm{M}_{30}$ ), with large, round to angular pores (1-2 per $\mathrm{mm}$ ), and small, cylindrical basidiospores (3.0-3.5 $\times 1.4-2.0 \mu \mathrm{m})$.

Distribution in Brazil: previously only recorded for the Atlantic forest in Brazil in the State of Paraná (Ryvarden $\&$ de Meijer 2002) and now also for São Paulo.

Specimens examined: BRAZIL. São Paulo: São Luiz do Paraitinga, Parque Estadual da Serra do Mar, Núcleo Santa Virgínia, 25-IV-2014, R.M. Pires 299 (SP-466227); 26-IV-2014, R.M. Pires 318 (SP446275).

Ceriporiopsis flavilutea (Murrill) Ryvarden $\equiv$ Poria flavilutea Murrill, Mycologia 13(3): 176 (1921)

Figure 4

Polyporales, Phanerochaetaceae

Description: Lowe (1966).

Remarks: Ceriporiopsis flavilutea is recognized by its annual and small basidiomata up to $1 \mathrm{~mm}$ thick, with white and cottony margins, small angular pores (6-8 per $\mathrm{mm})$ and small basidiospores $(2.5-3.5 \times 1.5-2.0 \mu \mathrm{m})$.

Distribution in Brazil: previously only recorded in the Atlantic forest in Brazil in the State of Rio Grande do Norte (Gibertoni et al. 2004) and now in São Paulo.
Specimen examined: BRAZIL. São PAUlo: São Luiz do Paraitinga, Parque Estadual da Serra do Mar, Núcleo Santa Virgínia, 13-VI-2013, R.M. Pires et al. 87 (SP-466094).

Dichomitus campestris (Quél.) Domanski \& Orlicz $\equiv$ Trametes campestris Quél., Mémoires de la Société d'Émulation de Montbéliard 5:286 (1872)

Figure 5

\section{Polyporales, Polyporaceae}

Description: Basidiomata annual to perennial, resupinate, typically cushion-shaped, distinctly thickened in the center, oblong to oval, up to 15 $\mathrm{mm}$ thick in center and up to $10 \mathrm{~cm}$ long. Margin narrow, dirty ochraceous to blackish (Küppers color chart: $\mathrm{N}_{99} \mathrm{~A}_{70} \mathrm{M}_{70}$ ). Pore surface tan to straw (Küppers color chart: $\mathrm{N}_{20} \mathrm{~A}_{60} \mathrm{M}_{30}$ ) with angular pores (1-2 per $\mathrm{mm}$ ). Hyphal system dimitic; generative hyphae clamped, hyaline, thin-walled, 2.5-4.0 $\mu \mathrm{m}$ wide; binding hyphae hyaline, thick-walled, straight to slightly sinuous, dichotomous branching, dextrinoid, (3.5-)4.0-8.0 $\mu \mathrm{m}$ wide. Basidiospores cylindrical, hyaline and thin-walled, negative in Melzer's reagent, $10-13 \times 4.5-5.5 \mu \mathrm{m}, \mathrm{Q}=2.0-2.7$ and $\mathrm{Q}_{\mathrm{m}}=2.4$.

Remarks: the cushion-shaped basidiomata with blackish margins are diagnostic for this species. The basidiospores of our material are slightly shorter than described by Ryvarden \& Gilbertson (1993), $(13-19 \times 4.0-5.5 \mu \mathrm{m})$, but similar to those materials described in Domansky \& Orlikz (1966), $(9.0-12.5 \times 3.5-4.5 \mu \mathrm{m})$ and this may be considered a normal variation within the species. This species is common in Europe and considered rare in America, recorded from United Stated and Mexico by Ryvarden \& Gilbertson (1993).

Distribution in Brazil: this is the first record of the species in Brazil, and as far as we known it is the first record of the species in South America and in the phytogeographic domain of the Atlantic Forest.

Specimen examined: BRAZIL. São PAUlo: São Luiz do Paraitinga, Parque Estadual da Serra do Mar, Núcleo Santa Virgínia, 13-VI-2013, R.M. Pires et al. 51 (SP-466079).

Diplomitoporus navisporus Gibertoni \& Ryvarden Figure 6

Polyporales, Polyporaceae

Description: Gibertoni et al. (2004). 
Remarks: the species presents perennial and resupinate basidiomata, a trimitic hyphal system and fusoid cystidioles. The navicular basidiospores, 4.1-5.0 $\times$ 2.0-2.7 $\mu \mathrm{m}$ in size, and the small regular pores (7-9 per $\mathrm{mm}$ ) are diagnostic.

Distribution in Brazil: this species was only known from the type locality in Pernambuco state (Gibertoni et al. 2014). This study represents the first record of the species in São Paulo State.

Specimens examined: BRAZIL. São Paulo: São Luiz do Paraitinga, Parque Estadual da Serra do Mar, Núcleo Santa Virgínia, 31-X-2013, R.M. Pires et al. 180 (SP-466153).

Flaviporus venustus A. David \& Rajchenb. Figure 7

Polyporales, Meruliaceae

Description: David \& Rajchenberg (1985).

Remarks: this species is very easy to recognize in field due to its fleshy and large basidiomata, whitish pink (Küppers color chart: $\mathrm{A}_{10} \mathrm{M}_{40} \mathrm{C}_{00}$ ), translucid and brittle. The species shrinks when dried, becoming rigid and hard. Microscopically, it is characterized by the small, ovoid basidiospores (3.5-4.5 $\times 2.5-3.2 \mu \mathrm{m})$ and the monomitic hyphal system with hyphae deeply immersed in a resinous substance, which makes them difficult to be observed in dried specimens.

Distribution in Brazil: previously only known from the southern region of Brazil in Paraná, Santa Catarina and Rio Grande do Sul States (Ryvarden \& de Meijer 2002, Silveira \& Guerrero 1991). This study represents the first record of the species in the southeast region of Brazil, in São Paulo State.

Specimen examined: BRAZIL. São Paulo: São Luiz do Paraitinga, Parque Estadual da Serra do Mar, Núcleo Santa Virgínia, 12-II-2014, R.M. Pires et al. 262 (SP-466208).

Grammothele fuligo (Berk. \& Broome) Ryvarden $\equiv$ Polyporus fuligo Berk. \& Broome, Botanical Journal of the Linnean Society 14: 53 (1875)

Figure 8

\section{Polyporales, Polyporaceae}

Description: Reck \& Silveira (2009).

Remarks: the species can be recognized by its association with monocotyledons, and macroscopically by the annual, resupinate, widely effused and strongly adnate basidiomata and by the bluish gray pore surface (Küppers color chart: $\mathrm{N}_{40} \mathrm{M}_{00} \mathrm{C}_{00}$ ). Grammothele fuligo is separated from other species of the genus by the smaller pores (7-10 per $\mathrm{mm}$ ).

Distribution in Brazil: the species was previously known from the Amazonas, Roraima and Santa Catarina states (Loguercio-Leite 1990, Reck \& Silveira 2009). This study represents the first record of the species in São Paulo State and Southeast region.

Specimen examined: BRAZIL. São PAUlo: São Luiz do Paraitinga, Parque Estadual da Serra do Mar, Núcleo Santa Virgínia, 19-XII-2013, R.M. Pires et al. 211 (SP-466176).

Oxyporus latemarginatus (Durieu \& Mont.) Donk $\equiv$ Polyporus latemarginatus Durieu \& Mont., Sylloge generum specierumque plantarum cryptogamarum: 163 (1856)

Figure 9

Hymenochaetales, Schizoporaceae

Description: Ryvarden \& Gilbertson (1994)

Remarks: Oxyporus latemarginatus is recognized by the resupinate white to straw (Küppers color chart: $\mathrm{N}_{00} \mathrm{~A}_{50} \mathrm{M}_{10}$ ) basidiomata. Microscopically, it is characterized by the monomitic hyphal system, generative hyphae with simple septa, rather small, apically encrusted cystidia $(13-30 \times 4.0-7.0 \mu \mathrm{m})$ and ellipsoid basidiospores $(3.8-4.8 \times 2.6-3.2 \mu \mathrm{m})$.

Distribution in Brazil: the species was previously known from the Paraná, Santa Catarina and Rio Grande do Sul states (Ryvarden \& de Meijer 2002, Loguercio-Leite et al. 2008, Baltazar \& Gibertoni 2009). This study represents the first record of the species in the southeast region of Brazil, in São Paulo State.

Specimen examined: BRAZIL. São PAULO: São Luiz do Paraitinga, Parque Estadual da Serra do Mar, Núcleo Santa Virgínia, 12-II-2014, R.M. Pires et al. 260 (SP-466206).

Postia subcaesia (A. David) Jülich $\equiv$ Tyromyces subcaesius A. David, Bulletin Mensuel de la Société Linnéenne de Lyon 43: 120 (1974)

Figure 11

Polyporales, Fomitopsidaceae

Description: Ryvarden \& Gilbertson (1994). 
Remarks: macroscopically, P. subcaesia has soft and watery basidiomata when fresh, white to ochraceous pileus (Küppers color chart: $\mathrm{N}_{30} \mathrm{C}_{10} \mathrm{~A}_{00}$ ), with slightly grayish to bluish tints in spots and pubescent pileus surface. Microscopically, the allantoid and slightly amyloid basidiospores (4.0-5.0 × 1.0-1.2) and metachromatic generative hyphae are helpful in the identification.

Distribution in Brazil: previously only known from the southern region of Brazil in Paraná, Santa Catarina and Rio Grande do Sul states (Ryvarden \& de Meijer 2002, Loguercio-Leite et al. 2008). This study represents the first record of the species in the southeast region of Brazil in São Paulo State.

Specimens examined: BRAZIL. São Paulo: São Luiz do Paraitinga, Parque Estadual da Serra do Mar, Núcleo Santa Virgínia, 12-VI-2013, R.M. Pires et al. 75 (SP-466088); R.M. Pires et al. 78 (SP-466089); 29-X-2013, R.M. Pires et al. 139 (SP-466124).

Postia tephroleuca (Fr.) Jülich $\equiv$ Polyporus tephroleucus Fr., Systema Mycologicum 1: 360 (1821)

Figure 12

\section{Polyporales, Fomitopsidaceae}

Description: Ryvarden \& Gilbertson (1994).

Remarks: Postia tephroleuca is distinguished by the velvety to tomentose pileus, pores (3-4 per $\mathrm{mm}$ ), monomitic hyphal system, clamped and metachromatic generative hyphae and by the cylindrical to allantoid basidiospores (4.5-6.0 × 1.0-1.5 $\mu \mathrm{m})$. Postia tephroleuca is reported in the literature as a species that produces brown rot and is similar to Tyromyces leucomallus (Berk. \& Curt.) Murril. However, $T$. leucomallus has smaller pores $(5-7$ per $\mathrm{mm})$ and smaller basidiospores $(3.5-4.5 \times 1.0 \mu \mathrm{m})$.

Distribution in Brazil: previously only known from the southern region of Brazil in Paraná and Rio Grande do Sul states (Ryvarden \& de Meijer 2002, Baltazar \& Gibertoni 2009). This study represents the first record of the species in the southeast region of Brazil, in São Paulo State.

Specimen examined: BRAZIL. São Paulo: São Luiz do Paraitinga, Parque Estadual da Serra do Mar, Núcleo Santa Virgínia, 27-IV-2014, R.M. Pires 331 (SP-466249).
Postia undosa (Peck) Jülich $\equiv$ Polyporus undosus Peck, Annual Report on the New York State Museum of Natural History 34: 42 (1881)

Figure 13

\section{Polyporales, Fomitopsidaceae}

Description: Basidiomata annual, effused-reflexed to resupinate, with a narrow and elongated pileus, single or imbricate with numerous small pilei and pore surface decurrent. Margin characteristically undulate; upper surface white to light cream (Küppers color chart: $\mathrm{N}_{10} \mathrm{~A}_{40} \mathrm{M}_{30}$ ), finely adpressed velutinate, becoming glabrous and smooth with age, pore surface cream, pores angular to irregular, 2-3 per mm. Hyphal system monomitic, generative hyphae clamped and metachromatic, contextual hyphae rarely to frequently branched, with abundant clamps, thick-walled, 3.5-7.0 $\mu \mathrm{m}$ and generative hyphae in the subhymenium rather thin-walled, 2.0-4.0 $\mu \mathrm{m}$. Basidiospores cylindrical to allantoid, hyaline and smooth, negative in Melzer's reagent, 4.0-5.0 × 1.5-2.1 $\mu \mathrm{m}, \mathrm{Q}=2.2-2.9$ and $\mathrm{Q}_{\mathrm{m}}=2.5$.

Remarks: the undulate margin and the large pores are good field characters (Ryvarden \& Gilbertson 1994). Furthermore, the cylindrical to allantoid basidiospores and metachromatic generative hyphae are important to distinguish this species. Postia undosa is widely distributed in the Northern Hemisphere, found on gymnosperms or rarely on angiosperms in southern Canada, the northern half of the United States and in Europe; associated with brown rot (Lowe 1966). In Africa, is was only observed on angiosperms (Ryvarden \& Johansen 1980). Our specimen was found growing on a dead log, preventing the identification of the plant.

Distribution in Brazil: This is the first record of the species in Brazil, and as far as we known it is the first record of the species in South America.

Specimen examined: BRAZIL. São PAUlo: São Luiz do Paraitinga, Parque Estadual da Serra do Mar, Núcleo Santa Virgínia, 31-X-2013, R.M. Pires 189 (SP-466161).

Identification key to species of Polyporales and similar genera (Basidiomycota) from Parque Estadual da Serra do Mar

1. Basidiomata stipitate to pseudo-stipitate

2. Basidiospores double-walled, endospore ornamented Amauroderma sprucei

2. Basidiospores simple-walled

3. Stipe dark-brown to black, not concolorous with the pileus 
4. Pileus surface tan to beige; pores 1-2 per mm Polyporus guianensis

4. Pileus surface dark brown to black; pores 5-7(-10) per mm Polyporus dictyopus

3. Stipe cream to brown, concolorous with the pileus

5. Pileus margin usually ciliate; pores (4-)5-7 per mm Polyporus ciliatus

5. Pileus margin non-ciliate, pores $1-5$ per $\mathrm{mm}$

6. Pileus surface white to pale brown; pores 1-2 per mm Polyporus tenuiculus

6. Pileus surface ochraceous to tan; pores 3-5 per mm ...

1. Basidiomata resupinate to pileate sessile

7. Basidiomata strictly resupinate

8. Generative hyphae with simple septa

9. Hyphal system dimitic

Flaviporus subundatus

9. Hyphal system monomitic

10. Basidiomata in shades of orange

11. Cystidia absent in the trama or hymenium

11. Cystidia present in the trama or hymenium

Rigidoporus crocatus

12. Pore surface pinkish to brown-orange when fresh, becoming brownish to blackish in dried specimens; basidiospores subglobose 4.0-5.0 ×3.0-4.0 $\mu \mathrm{m}$. Rigidoporus vinctus

12. Pores surface isabelline to ochraceous, almost unchanging when dry; basidiospores globose, $(4.0-) 5.5-6.0 \mu \mathrm{m}$ diam. Rigidoporus undatus

10. Basidiomata in a different color, never in shades of orange

13. Cystidia present in the trama or hymenium

Oxyporus latemarginatus

13. Cystidia absent in the trama or hymenium

14. Pore surface white; pores 1-3 per mm; basidiospores 4.0-5.0(-6.0) $\times 3.5-4.5(-5.0) \mu \mathrm{m}$ Ceriporia xylostromatoides

14. Pore surface yellow; pores 7-8 per mm; basidiospores 2.5-3.5 $\times 1.5-2.0 \mu \mathrm{m}$

8. Generative hyphae with clamps

Ceriporiopsis flavilutea

15. Skeletal hyphae dextrinoid

16. Basidiospores dextrinoid Grammothelopsis puiggarii

16. Basidiospores non-dextrinoid

17. Basidiospores ornamented Pachykytospora alabamae

17. Basidiospores smooth

18. Basidiomata white to cream

19. Pores 1-3 per mm; hyphal pegs present

Dichomitus setulosus

19. Pores (2-)4-5 per mm; hyphal pegs absent

Dichomitus cavernulosus

18. Basidiomata ochraceous to blackish

20. Basidiomata with a distinct blackish margin; pores 1-2(-3) per mm; basidiospores 10-13 $\times$ 4.5-5.5 $\mu \mathrm{m}$

Dichomitus campestris

20. Basidiomata with an ochraceous margin; pores 3-4 per mm; basidiospores $8.0-10 \times 2.5-3.0 \mu \mathrm{m}$

Dichomitus cylindrosporus

15. Skeletal hyphae non-dextrinoid

21. Basidiospores ornamented

Trechispora regularis

21. Basidiospores smooth

22. Cystidia present in the trama or hymenium

23. Basidiomata white to cream; capitate cystidioles present

24. Pores 2-3 per mm; basidiospores (4.5-)5.0-6.5 × 3.0-4.0(-5.0) $\mu \mathrm{m}$.... Schizopora paradoxa

24. Pores 5-6(-7) per mm; basidiospores 3.0-4.5(-5.0) $\times(2.0-) 2.5-3.0 \mu \mathrm{m}$

23. Basidiomata in a different color; capitate cystidioles absent

Schizopora flavipora

25. Basidiomata yellowish, becoming red when bruised; pores 3-6 per mm .... Junghuhnia carneola 25. Basidiomata pinkish, not becoming red when bruised; pores 6-10 per mm 
22. Cystidia absent in the trama or hymenium

26. Pore surface reddish-violet to lilac grey

27. Basidiospores ellipsoid to subglobose, 4.0-5.0(-5.5) $\times 2.5-3.0 \mu \mathrm{m}$; dendrohyphidia absent; red staining the substrate; usually on dicotyledons

. Tinctoporellus epimiltinus

27. Basidiospores cylindrical, (5.5-)6.0-8.0 $\times 3.0-3.5 \mu \mathrm{m}$; dendrohyphidia present; no red staining the substrate; on monocotyledons Grammothele fuligo

26. Pore surface white to pale brown

28. Hyphal system dimitic; basidiospores lunate, 0.5-1.0 $\mu \mathrm{m}$ wide; hyphal top with rosette-shaped crystals Sidera lenis

28. Hyphal system trimitic; basidiospores in a different form; without rosetteshaped crystals

29. Pores 4-6 per mm; basidiospores cylindrical to slightly allantoid $4.5-5.5 \times 2.5-3.0 \mu \mathrm{m}$ Cinereomyces dilutabilis

29. Pores 7-9 per mm; basidiospores navicular, 4.5-5.4 × 2.0-2.7 $\mu \mathrm{m}$

Diplomitoporus navisporus

7. Basidiomata effused-reflexed to pileate

30. Hyphal system monomitic

31. Generative hyphae with simple septa

32. Gloeopleurous hyphae present Henninsia brasiliensis

32. Gloeopleurous hyphae absent

33. Cystidia present in the trama or hymenium Rigidoporus lineatus

33. Cystidia absent in the trama or hymenium Rigidoporus microporus

31. Generative hyphae with clamps

34. Basidiospores allantoid; generative hyphae with metachromatic reaction

35. Pileus margin undulate; pores 2-3 per $\mathrm{mm}$ Postia undosa

35. Pileus margin indistinct; pores smaller

36. Basidiospores slightly amyloid in Melzer's reagent; hyphal pegs absent; upper surface white to ochraceous with slight grayish to bluish tints in spots and streaks, pubescent Postia subcaesia

36. Basidiospores non-amyloid in Melzer's reagent; hyphal pegs presents; upper surface cream-coloured to mouse-grey, coarsely strigose Postia tephroleuca

34. Basidiospores in other form; generative hyphae without metachromatic reaction

37. Basidiomata white to pinkish-red

38. Pores 6-10 per mm; basidiospores subglobose, 3.5-4.5 $\times 2.5-3.2 \mu \mathrm{m}$... Flaviporus venustus

38. Pores 1-3 per mm; basidiospores ellipsoid to broadly ellipsoid, 4.6-6.0 $\times 3.3-4.3 \mu \mathrm{m}$

Spongipellis caseosus

37. Basidiomata ochraceous to brownish

39. Pores 4-6 per mm; basidiospores broadly ellipsoid to ovoid, 4.50-6.0 $\times 4.0-5.0 \mu \mathrm{m}$ Loweomyces fractipes

39. Pores 2-4 per mm; basidiospores short-cylindrical, 5.5-7.0 $\times 2.5-3.5 \mu \mathrm{m}$

Bjerkandera fumosa

30. Hyphal system di-trimitic

40. Generative hyphae with simple septa Laetiporus gilbertsonii

40. Generative hyphae with clamps

41. Basidiomata perennial, ungulate to applanate, up to $10 \times 18 \times 10 \mathrm{~cm}$, gray, dark-brown to black; pores 7-10 per mm; basidiospores yellow to rusty brown Fomes fasciatus

41. Basidiomata different shaped 42. Skeletal hyphae dextrinoid 
43. Basidiospores non-dextrinoid to slightly-dextrinoid, yellowish-brown with slightly thickened walls and non-truncate, (3.6-)3.8-5.0 $\times 2.2-3.2(-3.4) \mu \mathrm{m}$

Abundisporus subflexibilis

43. Basidiospores strongly dextrinoid, hyaline and truncate, $12-17(-20) \times 7.0-10(-11) \mu \mathrm{m} . . . .$.

Truncospora ochroleuca

42. Skeletal hyphae non-dextrinoid

44. Basidiospores thick-walled and dextrinoid in mass

Perenniporiella neofulva

44. Basidiospores thin-walled and non-dextrinoid

45. Cystidia present in the trama or hymenium

46. Pileus surface grayish-brown to dark-brown; cystidia cylindrical, embedded apically, up to $15 \mu \mathrm{m}$ length Trichaptum sector

46. Pileus surface in a different color; cystidia larger, up to $100 \mu \mathrm{m}$ length

47. Pore surface white to ochraceous

48. Pores 5-6 per mm; basidiospores subglobose, 4.0-5.0 $\times 3.5-4.0 \mu \mathrm{m}$

Junghuhnia undigera

48. Pores 6-7 per mm; basidiospores broadly ellipsoid, 3.6-4.2 $\times 2.5-3.2 \mu \mathrm{m}$ Junghuhnia semisupiniformis

47. Pore surface pale straw to sulphurous yellow

49. Pore surface sulphurous yellow when fresh, paler when dry; basidiospores $2.6-2.8 \times 1.8-2.0 \mu \mathrm{m}$ Flaviporus brownii

49. Pore surface pale tan to pale straw, often darker in older specimens, brown to deep bay when dry; basidiospores $2.5-3.5 \times 1.5-2.5 \mu \mathrm{m}$ Flaviporus liebmannii

45. Cystidia absent in the trama or hymenium

50. Context white to cream to golden yellow

51. Chlamydospores presents in the dissepiment edges and cystidia ventricose 9.0-30 × 4.5-7.0 $\mu \mathrm{m}$

Echinoporia inermis

51. Chlamydospores absent and cystidia different shaped

52. Hyphal system dimitic

53. Basidiomata yellow to brownish yellow

54. Pores $7-8$ per $\mathrm{mm}$ Flaviporus subhydrophilus

54. Pores 1-2 per mm Antrodiella luteocontexta

53. Basidiomata white to pale brown

55. Basidiospores globose to broadly ellipsoid

56. Pores 7-10 per mm; skeletal hyphae densely agglutinated and difficult to separate in the dense context and the trama Flaviporus hydrophilus

56. Pores 2-6 per mm; skeletal hyphae nonagglutinated

57. Irregular pores $2-4$ per $\mathrm{mm}$ Antrodiella angulatopora

57. Regular pores 4-6(-7) per mm Antrodiella semisupina

55. Basidiospores allantoid to cylindrical

58. Pores 5-8 per mm; basidiospores allantoid, 4.0-6.0(-6.5) × 1.5-2.0 $\mu \mathrm{m}$ Antrodiella duracina

58. Pores 1-3 per mm; basidiospores cylindrical, (8.0-)9.5-14 × 3.5-5.0(-6.0) $\mu \mathrm{m}$ Antrodia albida

52. Hyphal system trimitic

59. Skeletal hyphae golden yellow Coriolopsis rigida

59. Skeletal hyphae hyaline 
60. Pores angular, $2-4$ permm; basidiospores 6.5-8.0 $\times 2.0-3.0(-3.5) \mu \mathrm{m}$ Trametes villosa

60. Pores circular, above 4 per $\mathrm{mm}$; basidiospores smaller 61. Pores 4-5 per mm; basidiospores cylindrical, 5.0-6.0 × 1.5-2.0 $\mu \mathrm{m} . . . .$. Trametes versicolor 61. Pores 5-8 per mm; basidiospores ellipsoid, $(3.0-) 3.5-4.5(-5.0) \times 2.5-3.0(-3.5) \mu \mathrm{m}$.... Trametes membranacea 50. Context brown to reddish-orange 62. Basidiomata orange to reddish-orange Pycnoporus sanguineus 62. Basidiomata of a different color, never orange 63. Crust dark-reddish to black on the pileus surface Fomitella supina 63. Crust absent on the pileus surface

64. Skeletal hyphae dark fuliginous-brown to dark golden 65. Basidiospores ornamented, double walled ....... Ganoderma australe 65. Basidiospores smooth, simple walled Coriolopsis caperata 64. Skeletal hyphae hyaline to yellowish

66. Pores irregular, sinuous to daedaleoid, pores 1-2 per $\mathrm{mm}$; dendrohyphidia present; basidiospores $5.0-7.0 \times 2.0-2.5 \mu \mathrm{m}$ Fuscocerrena portoricensis 66. Pores regular, pores above 2 per $\mathrm{mm}$; dendrohyphidia absent 67. Pores $2-3$ per mm; hyphal pegs absent; basidiospores cylindrical, 7.0-10 × 2.5-4.0 $\mu \mathrm{m}$ Antrodia malicola 67.Pores 8-10 per mm; hyphal pegs present; basidiospores allantoid, 4.0-5.0 × 0.5-1.0 $\mu \mathrm{m}$... Skeletocutis nivea

Table 1. Polypores and similar poroid genera recorded for the first time from Parque Estadual da Serra do Mar - Núcleo Santa Virgínia, São Paulo State, Brazil.

\begin{tabular}{lc}
\hline Order/Family/ species & Voucher \\
\hline Polyporales & \\
Fomitopsidaceae Jülich & \\
Antrodia aff. albida (Fr.) Donk & SP466098, SP466123, SP466150, SP466159, SP466220, \\
Antrodia malicola (Berk. \& M.A. Curtis) Donk & SP466237 \\
Laetiporus gilbertsonii Burds. & SP466077 \\
Ganodermataceae (Donk) Donk & SP466044, SP466045, SP466046 \\
Amauroderma sprucei (Pat.) Torrend & SP466165 \\
Ganoderma australe (Fr.) Pat. & SP445969, SP466059, SP466071, SP466137, SP466139, \\
Meripilaceae Jülich & SP466199 \\
Henningsia brasiliensis (Speg.) Speg. & \\
Rigidoporus crocatus (Pat.) Ryvarden & SP466163, SP4666170, SP466177, SP466179 \\
Rigidoporus lineatus (Pers.) Ryvarden & SP446270 \\
Rigidoporus microporus (Sw.) Overeem & SP466064, SP466148, SP466154, SP466166, SP466175, \\
Rigidoporus undatus (Pers.) Donk & SP466185, SP466196 \\
Rigidoporus vinctus (Berk.) Ryvarden & SP466114, SP466138 \\
Meruliaceae Rea & SP466099 \\
Bjerkandera fumosa (Pers.) P. Karst. & \\
Ceriporia xylostromatoides (Berk.) Ryvarden & \\
Flaviporus brownii (Humb.) Donk & SP4666155, SP466157, SP466198, SP466202, SP466211 \\
Flaviporus hydrophilus (Berk. \& M.A.Curtis) Ginns & SP466142 \\
\end{tabular}


Table 1 (continuation)

\begin{tabular}{|c|c|}
\hline Order/Family/species & Voucher \\
\hline Flaviporus liebmannii (Fr.) Ginns & $\begin{array}{c}\text { SP466065, SP466072, SP466074, SP466132, SP466171, } \\
\text { SP466172 }\end{array}$ \\
\hline $\begin{array}{l}\text { Flaviporus subhydrophilus (Speg.) Rajchenb. \& J.E. } \\
\text { Wright }\end{array}$ & SP446262, SP446274, SP466129 \\
\hline Flaviporus subundatus (Murrill) Ginns & SP446276 \\
\hline Loweomyces fractipes (Berk. \& M.A. Curtis) Jülich & SP466167 \\
\hline Phanerochaetaceae Jülich & \\
\hline Antrodiella angulatopora Ryvarden & SP445968, SP445970, SP446269, SP466230, SP466236 \\
\hline Antrodiella duracina (Pat.) I. Lindblad \& Ryvarden & $\begin{array}{c}\text { SP445966, SP446268, SP466086, SP466093, SP466149, } \\
\text { SP466162 }\end{array}$ \\
\hline $\begin{array}{l}\text { Antrodiella semisupina (Berk. \& M.A. Curtis) } \\
\text { Ryvarden }\end{array}$ & SP466076 \\
\hline Junghuhnia carneola (Bres.) Rajchenb. & SP446259 \\
\hline Junghuhnia nitida (Pers.) Ryvarden & SP445975 \\
\hline Junghuhnia semisupiniformis (Murrill) Ryvarden & SP446264 \\
\hline $\begin{array}{l}\text { Junghuhnia undigera (Berk. \& M.A. Curtis) Ryvarden } \\
\text { Polyporaceae Corda }\end{array}$ & SP466118, SP466223, SP466228, SP466235, SP466247 \\
\hline $\begin{array}{l}\text { Abundisporus subflexibilis (Berk. \& M.A. Curtis) } \\
\text { Parmasto }\end{array}$ & SP466116 \\
\hline $\begin{array}{l}\text { Cinereomyces dilutabilis (Log.-Leite \& J. E. Wright) } \\
\text { Miettinen }\end{array}$ & SP446258, SP466181 \\
\hline Coriolopsis caperata (Berk.) Murrill & SP466169 \\
\hline Coriolopsis rigida (Berk. \& Mont.) Murrill & $\begin{array}{c}\text { SP466087, SP466103, SP466126, SP466130, SP466147, } \\
\text { SP466160, SP466194 }\end{array}$ \\
\hline Dichomitus cavernulosus (Berk.) Masuka \& Ryvarden & SP466188, SP466238 \\
\hline Dichomitus cylindrosporus Ryvarden & SP466096, SP446261 \\
\hline Dichomitus setulosus (Henn.) Masuka \& Ryvarden & SP466242 \\
\hline Fomes fasciatus (Sw.) Cooke & SP445965, SP466083, SP466173 \\
\hline Fomitella supina (Sw.) Ryvarden & $\begin{array}{c}\text { SP445964, SP445967, SP466067, SP466082, SP466174, } \\
\text { SP466195, SP466251 }\end{array}$ \\
\hline Fuscocerrena portoricensis (Fr.) Ryvarden & SP466107, SP466115 \\
\hline $\begin{array}{l}\text { Grammothelopsis puiggarii (Speg.) Rajchenb. \& J.E. } \\
\text { Wrigh }\end{array}$ & SP466120 \\
\hline Pachykytospora alabamae (Berk. \& Cooke) Ryvarden & SP466128 \\
\hline Perenniporiella neofulva (Lloyd) Decock \& Ryvarden & SP466219 \\
\hline Polyporus ciliatus Fr. & SP466119, SP466122, SP466135, SP466141 \\
\hline Polyporus dictyopus Mont. & SP466145, SP466190, SP466209, SP466229, SP466250 \\
\hline Polyporus grammocephalus Berk. & SP466187 \\
\hline Polyporus guianensis Mont. & SP466207 \\
\hline Polyporus tenuiculus (P. Beauv.) Fr. & SP466060, SP466151, SP466183, SP466197, SP466201 \\
\hline Pycnoporus sanguineus (L.) Murrill & SP445972, SP445973 \\
\hline Skeletocutis nivea (Jungh.) Jean Keller & SP446267 \\
\hline Spongipellis caseosus (Pat.) Ryvarden & SP466117 \\
\hline Tinctoporellus epimiltinus (Berk. \& Broome) Ryvarden & SP445977, SP466068, SP466178 \\
\hline Trametes membranacea (Sw.) Kreisel & SP466127 \\
\hline Trametes versicolor (L.) Lloyd & SP466225 \\
\hline Trametes villosa (Sw.) Kreisel & SP445974, SP445976, SP466111 \\
\hline Truncospora ochroleuca (Berk.) Ryvarden & SP466218, SP466245 \\
\hline
\end{tabular}




\section{Table 1 (continuation)}

\begin{tabular}{lc}
\hline Order/Family/ species & Voucher \\
\hline Rickenellaceae Vizzini & SP466075, SP466095, SP466097, SP466101, SP466105, \\
& SP466109, SP466110, SP466158, SP466182, SP466186, \\
Sidera lenis (P. Karst.) Miettinen & SP466191, SP466203, SP466215, SP46622, SP466243 \\
& \\
Hymenochaetales & SP466090, SP466152, SP466232 \\
Schizoporaceae Jülich & SP466062, SP466063, SP466091, SP466140, SP466143, \\
Echinoporia inermis G. Coelho & SP466231 \\
Schizopora flavipora (Berk. \& M.A. Curtis ex Cooke) & SP466146, SP466156, SP466168, SP466184, SP466222, \\
Ryvarden & SP466125, SP466212, SP466213, SP466234 \\
Schizopora paradoxa (Schrad.) Donk & SP445971, SP466084 \\
Incertae sedis & \\
Trichaptum sector (Ehrenb.) Kreisel & \\
Trechisporales & \\
Hydnodontaceae Jülich & SP466193, SP466224, SP466226 \\
Trechispora regularis (Murrill) Liberta & \\
\hline
\end{tabular}
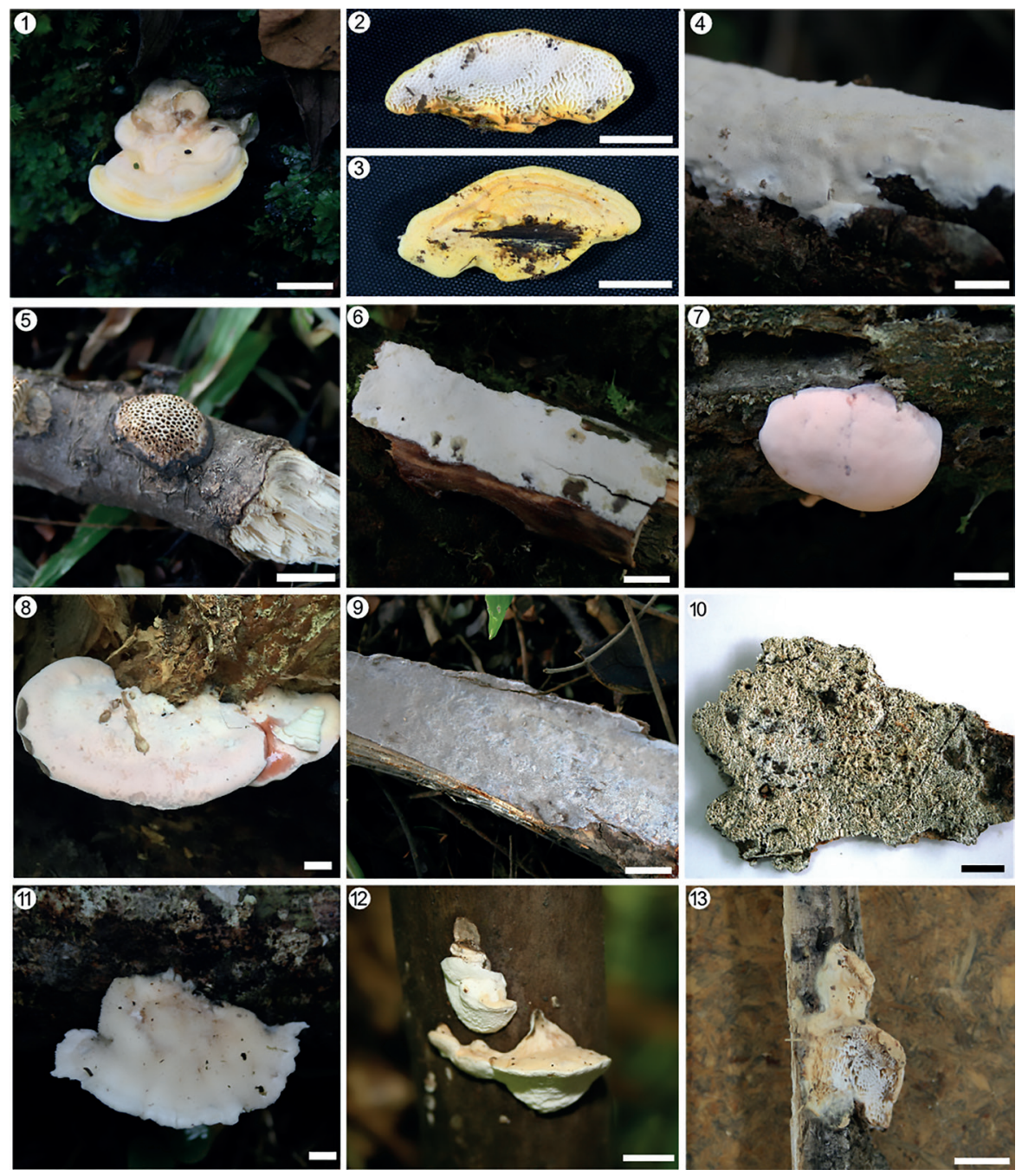

Figure 1-13. Fresh basidiomata. 1-3. Antrodiella luteocontexta. 4. Ceriporiopsis flavilutea. 5. Dichomitus campestris. 6. Diplomitoporus navisporus. 7-8. Flaviporus venustus. 9. Grammothele fuligo. 10. Oxyporus latemarginatus. 11. Postia subcaesia. 12. Postia tephroleuca. 13. Postia undosa. Scale bar $=1 \mathrm{~cm}$. 
All the 68 collections represent the first record to the PESM. An identification key and a table including the other specimens recorded for the first time in the locality are presented (table 1 ).

\section{Acknowledgements}

The authors are grateful to the curators of the herbaria FLOR, PRM, S, SP and URM for the loan of type or original collections. Authors kindly acknowledge Instituto Florestal. We are grateful to Karina Ambrosio Claro for the photo of Flaviporus venustus. The first author is grateful to the financial support received from Fundação de Amparo à Pesquisa do Estado de São Paulo - FAPESP (2012/25493-7).

\section{Literature cited}

Abrahão, M.C., Gugliotta, A.M. \& Gomes, E. 2009. Poliporóides (Basidiomycota) em fragmentos de mata no perímetro urbano de São José do Rio Preto, São Paulo, Brasil. Revista Brasileira de Botânica 32: 427-440.

Baltazar, J.M. \& Gibertoni, T.B. 2009. A checklist of the aphyllophoroid fungi (Basdiomycota) recorded from the Atlantic Rain Forest. Mycotaxon 109: 439-442.

Begon, M., Towsend, C.R. \& Harper, J.L. 2006. Ecology: from individuals to ecosystems. Blackwell Publishing, Oxford.

Binder, M., Hibett, D.S., Larsson, K.H., Larsson, E., Langer, E. \& Langer, G. 2005. The phylogenetic distribution of resupinate forms across the major clades of mushroom-forming fungi (Homobasidiomycetes). Systematics and Biodiversity 3: 113-157.

Binder, M., Justo, A., Riley, R., Salamov, A., LópezGiráldez, F., Sjökvist, E., Copeland, A., Foster, B., Sun, H., Larsson, E., Larsson, K.H., Townsend, J., Grigoriev, I.V. \& Hibbett, D.S. 2013. Phylogenetic and phylogenomic overview of the Polyporales. Mycologia 105: 1350-1373.

Bononi, V.L.R., Trufem, S.F.B. \& Grandi, R.A.P. 1981. Fungos macroscópicos do Parque Estadual das Fontes do Ipiranga, depositados no Herbário do Instituto de Botânica. Rickia 9: 37-53.

Coelho, G. 2005. Brazilian new species of Auriporia. Mycologia 97: 266-270.

David, A. \& Rajchenberg, M. 1985. Pore fungi from French Antilles and Guiana. Mycotaxon 22: 285-325.

Domansky, S., \& Orlikz, A. 1966. Dichomitus campestris (Quél.) comb. nov. w Polsce. Acta Societatis Botanicorum Poloniae 35: 627-636.

Fidalgo, O. \& Bononi, V.L.R. 1984. Técnicas de coleta, preservação e herborização de material botânico. Instituto de Botânica, São Paulo, n. 4.
Fundação SOS Mata Atlântica and Instituto Nacional de Pesquisas Espaciais - INPE. 2009. Atlas dos remanescentes florestais da Mata Atlântica, Período 2005 a 2008. Available in http://www.sosma.org.br (access in 06-IX-2014).

Fundação SOS Mata Atlântica and Instituto Nacional de Pesquisas Espaciais - INPE. 2011. Atlas dos remanescentes florestais da Mata Atlântica, Período 2008 a 2012. Available in http://www.sosma.org.br (access in 06-IX-2014).

Garcia-Sandoval, R., Wang, Z., Binder, M. \& Hibbett, D.S. 2011. Molecular phylogenetics of the Gloeophyllales and relative ages of clades of Agaricomycotina producing a brown rot. Mycologia 103: 510-524.

Gibertoni, T.B., Ryvarden, L. \& Queiros Cavalcanti, M.A. 2004. Studies in Neotropical polypores 18 New species from Brazil. Synopsis. Fungorum 18: 44-56.

Gugliotta, A.M. \& Bononi, V.L.R. 1999. Polyporaceae do Parque Estadual da Ilha do Cardoso, São Paulo, Brasil. Boletim do Instituto de Botânica 12: 1-112.

Gugliotta, A.M., Fonsêca, M.P. \& Bononi, V.L.R. 2010. Additions to the knowledge of aphyllophoroid fungi (Basidiomycota) of Atlantic Rain Forest in São Paulo State, Brazil. Mycotaxon 112: 335-338.

Gugliotta, A.M., Gibertoni, T.B., Drechsler-Santos, E.R., Silveira, R.M.B., Chikowski, R.S., Pires, R.M., Montoya, C.A.S., Souza, J.F., Palacio, M. \& Rezende, D.H.C. 2015. Polyporales. In: Lista de Espécies da Flora do Brasil. Jardim Botânico do Rio de Janeiro. Available in http://floradobrasil.jbrj.gov.br/jabot/floradobrasil/ FB92526 (access in 11-III-2015).

Gugliotta, A.M., Poscolere, G.D. \& Campacci, T.V.S. 2011. Criptógamos do Parque Estadual das Fontes do Ipiranga, São Paulo, SP, Brasil. Fungos, 10: Ganodermataceae Hoehnea 38: 687-695.

Hibbett, D.S. \& Donoghue, M.J. 1995. Progress toward a phylogenetic classification of the Polyporaceae through parsimony analyses of ribosomal DNA sequences. Canadian Journal of Botany 73: 853-861.

Jesus, M.A. 1993. Basidiomicetos lignocelulolíticos de floresta nativa e de Pinus elliottii Engelm. do Parque Estadual das Fontes do Ipiranga, São Paulo, SP. Hoehnea 20:119-126.

Küppers, H. 2002. Atlas de los colores. Editorial Blume, Barcelona.

Larsson, K.H., Larsson, E. \& Kõljalg, U. 2004. High phylogenetic diversity among corticioid Homobasidiomycetes. Mycological Research 108: 983-1002.

Leal, G.R. \& Gugliotta, A.M. 2008. Criptógamos do Parque Estadual das Fontes do Ipiranga, São Paulo, SP. Fungos, 9: Meripilaceae. Hoehnea 35: 99-110.

Loguercio-Leite, C. 1990. Revisão histórica sobre fungos poliporóides (Aphyllophorales) xilófilos de Santa Catarina, Brasil. Insula 20: 3-10. 
Loguercio-Leite, C, Michels, J. \& J.M. Baltazar. 2008. Austro-American lignolytic polypores (Agaricomycetes) - new records for Southern Brazil. Mycotaxon 104: 205-213.

Louza, G.S.G. \& Gugliotta, A.M. 2007. Polyporus Fr. (Polyporaceae) no Parque Estadual das Fontes do Ipiranga, São Paulo, SP, Brasil. Hoehnea 34: 365-382.

Lowe, J.L. 1966. Polyporaceae of North America. The genus Poria. Technical Publication of the State University College of Forestry at Syracuse University 90: 1-183.

Miettinen, O, Larsson, E., Sjökvist, E. \& Larsson, K.L. 2011. Comprehensive taxon sampling reveals unaccounted diversity and morphological plasticity in a group of dimitic polypores (Polyporales, Basidiomycota). Cladistics 28: 251-7270.

Mittermeier, R.A., Gil, P.R., Hoffman, M., Pilgrim, J., Brooks, T., Mittermeier, C.G., Lamoreux, J. \& Fonseca, G.A.B. 2004. Hotspots revisited: earth's biologically richest and most endangered terrestrial Eco-regions. CEMEX \& Agrupacion Sierra Madre, Cidade do México.

Motato-Vásquez, V. \& Gugliotta, A.M. 2014. Polypores from an Atlantic rainforest area in southeast Brazil: resupinate species. Brazilian Journal of Botany 37: 175-185.

Motato-Vásquez, V., Pires, R.M. \& Gugliotta, A.M. 2015. Polypores from an Atlantic rainforest area in southeast Brazil: pileate species. Brazilian Journal of Botany 38: 149-164.

Pires, R.M. \& Gugliotta, A.M. 2016. Poroid Hymenochaetaceae (Basidiomycota) from Parque Estadual da Serra do Mar, Núcleo Santa Virgínia, São Paulo, Brazil. Rodriguésia 67: 667-676.

Reck, M.A. \& Silveira, R.M.B. 2009. Grammothele species from southern Brazil. Mycotaxon 109: 361-372.

Ryvarden, L. 1991. Genera of polypores, nomenclature and taxonomy. Synopsis Fungorum. 5: 1-373.

Ryvarden, L. \& Gilbertson, R.L. 1993. European polypores. Part 1. Synopsis Fungorum 6: 1-387.
Ryvarden, L. \& Gilbertson, R.L. 1994. European polypores. Part 2. Synopsis Fungorum 7: 394-743.

Ryvarden L. \& Johansen, I. 1980. A preliminary polypore flora of East Africa. Fungiflora, Oslo.

Ryvarden, L. \& de Meijer, A.A.R. 2002. Studies in Neotropical polypores 14. New species from the state of Paraná, Brazil. Synopsis Fungorum 15: 34-69.

Secretaria de Estado de Meio Ambiente. 1996. Atlas das Unidades de Conservação Ambiental do Estado de São Paulo - parte I litoral. Secretaria do Meio Ambiente, São Paulo.

Secretaria de Estado de Meio Ambiente. 2000. Atlas das Unidades de Conservação Ambiental do Estado de São Paulo - parte II interior. Secretaria do Meio Ambiente, São Paulo.

Secretaria de Estado de Meio Ambiente. 2008. Plano de manejo do PESM. Secretaria de Estado do Meio Ambiente, São Paulo. Available in http://www.cbs.knaw. $\mathrm{nl} / \mathrm{http}$ ://fflorestal.sp.gov.br/planos-de-manejo/planosde-manejo-planos-concluidos/ (access in 10-II-2014).

Silveira, R.M.B \& Guerrero, R.T. 1991. Aphyllophorales poliporóides (Basidiomycetes) do Parque Nacional de Aparados da Serra, Rio Grande do Sul. Boletim do Instituto de Biociências. Universidade Federal do Rio Grande do Sul 48: 1-127.

Westphalen, M.C., Reck, M.A \& Silveira, R.M.B. 2010. Polypores from Morro Santana, Rio Grande do Sul, Brazil. Hoehnea 37: 647-662.

Westphalen, M.C. \& Silveira, R.M.B. 2008. Resupinate polypores from mixed ombrophilous forests in southern Brazil. Mycotaxon 122: 111-122.

Westphalen, M.C. \& Silveira, R.M.B. 2013. Pileate polypores from Araucaria Forests in Southern Brazil. Hoehnea 40: 77-86.

Xavier-Santos, S., Carvalho, C.C., Bonfá, M., Silva, R., Capelari, M. \& Gomes, E. 2004. Screening for pectinolytic activity of wood-rotting Basidiomycetes and characterization of the enzymes. Folia Microbiologica 49: 46-52. 